\title{
THE ENJOYABLE PHYSICAL EDUCATION LEARNING TO IMPROVE STUDENTS' MOTIVATION AND LEARNING ACHIEVEMENT
}

\author{
Fuaddi $^{1}$, Tomoliyus ${ }^{1}$, Pamuji Sukoco ${ }^{1}$, Soni Nopembri ${ }^{1}$ \\ ${ }^{1}$ Yogyakarta State University, Yogyakarta, Indonesia, anwar92fuaddi.af@gmail.com \\ https://doi.org/10.29038/2220-7481-2020-01-50-59
}

\begin{abstract}
s
Topicality. The using of appropriate learning model is the key in creating an effective, conducive, and enjoyable learning. Therefore, the supporting of teachers' learning literacy model becomes a research field should be renewed and improved. Research Purpose. The purposes of this research are: (a) to know how peer teaching can give motivation and improve the learning achievement of students. (b) The things should be noticed in implementing the peer teaching method. Methods. The method used in this research was literature study using research steps by Wolfswinkel et al. Research Result. The result of this research shows that the using of peer teaching learning model gives many academic benefits, one of them is the improvement of psychomotor aspect, cognitive aspect, and affective aspect of students. Besides that, another academic benefit obtained such as that learning model can train students' communication skill and also can elevate students' confidence which also can be obtained through the pear teaching learning model. From the analysis of all collected data, there are some recommendations. The peer teaching learning model can be used in every level of education. Peer teaching learning model will be more effective if accompanied by additional teaching media such as task card and other kinds of media. In many writings, the peer teaching learning method is often used in field practice learning which trains the psychomotor skill, but still can improve other domains such as cognitive and affective.
\end{abstract}

Key word: peer teaching, learning motivation, enjoyable learning.

Фуадді, Томоліюс, Памуджі Сукоко, Соні Нонембрі. Правильна фізична освіта для вдосконалення мотивації навчання студентів. Актуальність теми дослідження. Використання відповідної моделі навчання $\epsilon$ ключовим у формуванні ефективного, сприятливого та приємного процесу навчання. Тому підтримка моделі грамотності вчителів у процесі навчання стає галуззю дослідження, яку потрібно вдосконалювати. Мета дослідження - по-перше, з'ясувати, як навчання може мотивувати та покращити досягнення студентів; по-друге, виявити особливі риси при застосуванні такого методу навчання. Методи дослідження. Під час дослідження застосовано літературний метод із використанням поетапних досліджень Wolfswinkel. Результати дослідження. У результаті цього дослідження виявлено, що використання моделі навчання студентів-однолітків дає багато академічних переваг, одна з яких - удосконалення психомоторного, когнітивного та афективного аспектів у студентів. Крім того, ще однією академічною перевагою такої моделі навчання $є$ вироблення навичок спілкування студентів, підвищення їх власної упевненості. У результаті зібраних даних автором розроблено деякі рекомендації. Така модель навчання може бути використана для будь-якого освітнього рівня й стане ефективнішою, якщо супроводжуватиметься додатковими навчальними матеріалами, такими як картки завдань, та іншими види інформаційних засобів. Методика навчання однолітків часто розвиває психомоторні здібності, але все ж може покращити когнітивну та афективну майстерність.

Ключові слова: навчання однолітків, мотивація до навчання, приємне навчання.

Фуадди, Томолиюс, Памуджи Сукоко, Сони Нонембри. Правильное физическое образование для совершенствования мотивации обучения студентов. Актуальность темы исследования. Использование соответствующей модели обучения является ключевым в формировании эффективного, благоприятного и приятного процесса обучения. Поэтому поддержка модели грамотности учителей в процессе обучения становится областью исследования, которую нужно совершенствовать. Цель исследования - во-первых, выяснить, как обучение может мотивировать и улучшить достижения студентов; во-вторых, выявить особые черты при применении такого метода обучения. Методы исследования. Во время исследования применен литературный метод с использованием поэтапных исследований Wolfswinkel. Результаты исследования. В результате этого исследования выявлено, что использование модели обучения студентов-сверстников дает много академических преимуществ, одно из которых - совершенствование психомоторного, когнитивного и аффективного аспектов студентов. Кроме того, еще одним академическим преимуществом такой модели обучения является выработка навыков общения студентов, повышение их собственной уверенности. В результате собранных данных автором разработаны некоторые рекомендации. Такая модель обучения может быть использована для любого образовательного уровня и станет более эффективной, если будет сопровождаться дополнительными учебными материалами, такими как 
карточки задач, и другими видами информационных средств. Методика обучения сверстников часто развивает психомоторные способности, но все же может улучшить когнитивное и аффективное мастерство.

Ключевые слова: обучение сверстников, мотивация к обучению, приятное обучение.

Introduction. Doing a research and writing about learning models are some efforts in helping teachers to create the more effective, conducive, and enjoyable learning. Nowadays, teachers can use many learning models as their needs in teaching and an enjoyable learning condition will make students to be more motivated in learning [1]. Motivation is something that important in deciding students' achievement, it can force students to begin the learning and also help to maintain the learning motivation of students [2]. Hence, using a suitable learning model with a learning purpose is absolute for teachers [3]. Teaching students by using education principles or learning theory is the main aim of the success in education [4].

The peer tutor learning is the enjoyable way of learning and it can improve the learning motivation of students [5; 6]. According to [7] peer teaching is a set of learning practice where peer tutor teaches each other in an interaction which is promoted by a purpose, the most peer tutor education is conducted by the older people, have many experiences, or have many knowledge from the other friends.

The learning condition by the intimate peer tutor will make tutees follow the learning activity effectively because students will be free to manage their time in learning and the material mastering target which is expected. Therefore, the peer tutor method can be made as alternative learning method by teacher in a learning process [3]. Motivation is an important variable in education, it affects the improvement of education in other fields including the development of social skill, self-confidence and unyielding behavior $[8 ; 9 ; 10]$ find that motivated students in learning tend to be more active and have higher participation in learning. $[11 ; 12 ; 13]$ confirms that motivation has been proved as a predictor for learning, academic achievement, persistence or continuation in study and prosperity.

The lack of motivation obtained by students will affect the learning productivity. Besides that, it will cause students' boringness and unhappiness in joining the class $[14 ; 15 ; 16]$. Because of that, the motivation of students when learning becomes the main factor that should be well noticed by teacher, one of the efforts which can be done by teachers is by using learning method that can well motivate students.

For some decades, the research about general motivation in learning behavior and education is well researched [17], besides that, there are many researches about the improvement of motivation through the method of peer teaching learning. The good learning motivation is the requirement for the improvement of students' achievement. [18] States that the peer tutor learning is able to improve the academic achievement and other pedagogical benefits. [19] Emphasizes that peer tutor learning can significantly improve students' cognitive skill than compared with the conventional learning. Peer teaching has been proved as an effective learning strategy $[20 ; 21]$ in improving the quality of learning time, improving the physical activity, improving the moving skill, improving the healthy life behavior, developing interaction and social skill.

Because there are many articles discuss peer teaching learning model, the writer needs to summarize those researches in a writing to ease the teachers. This summary will focus in discussing about: (a) how peer teaching gives motivation and increase the learning achievement of students (b) the things should be considered in implementing the peer learning method.

Methods. This study is a literature review. The selection of study approach in this research was shown to see how peer teaching can give motivation and elevate students' learning achievement. The process of literature review in this study refers to the steps proposed by Wolfswinkel, et al. [23] There are five methods of literature review which consist of: 1) deciding the criteria; 2) finding; 3 ) selecting; 4) analyzing (synthesis); and 5) serving.

The finding of the articles in this study uses the findings in Google Scholar, Taylor \& Francis Online and Human Kinetics by using some keywords: «peer teaching», «peer teaching in a physical education» and «peer teaching in sport education» which were published at 2000 until 2018. Then, the appropriate finding of the articles selected in this study is adjusted with the purpose of study.

Results. For fulfilling the two research purposes in this research, it was conducted two groupings: (a) to see how peer teaching gives motivation and improves students' learning achievement. (b) Some things to be noticed in implementing peer tutor learning method. To be clearer, take a look to the explanation of the research findings in the table 1 below.

From the table 1 above, it can be seen that the peer teaching learning model is an enjoyable learning model for students, the selection of model with some considerations can improve motivation [24]. The psychological similarity between tutor and tutee and the involvement of motivation by tutee can indirectly improve intrinsic 
motivation of tutee [25] makes the learning process more alive, [26] the expertise level of tutor can also affect the improvement of tutee's motivation which indirectly affect the improvement of tutee's motoric skill.

Table 1

Peer Teaching Document in International Physical Education Learning

\begin{tabular}{|c|c|c|c|c|}
\hline Title & Author & $\begin{array}{c}\text { Published } \\
\text { Year }\end{array}$ & Method & Note / Result \\
\hline 1 & 2 & 3 & 4 & 5 \\
\hline $\begin{array}{l}\text { Peer-assisted learning in } \\
\text { school physical educa- } \\
\text { tion, sport and physical } \\
\text { activity programmes: a } \\
\text { systematic review }\end{array}$ & $\begin{array}{l}\text { Kate. A. Jenkinson, } \\
\text { Geraldine Naughton } \\
\text { and Amanda C. Ben- } \\
\text { son }\end{array}$ & 2002 & Systematic Review & $\begin{array}{l}\text { Peer teaching has been proved } \\
\text { as an effective learning stra- } \\
\text { tegy in improving quality of } \\
\text { learning time, improving the } \\
\text { physical activity, improving } \\
\text { the moving skill, improving } \\
\text { the healthy-life behavior, de- } \\
\text { veloping interaction and social } \\
\text { skill. }\end{array}$ \\
\hline $\begin{array}{l}\text { Peer influence on young } \\
\text { athletes' need satisfac- } \\
\text { tion, intrinsic motiva- } \\
\text { tion and persistence in } \\
\text { sport: A } 12 \text {-month pro- } \\
\text { spective study }\end{array}$ & $\begin{array}{l}\text { Helen Jõesaar a, Vello } \\
\text { Hein and Martin } \\
\text { S. Hagger }\end{array}$ & 2011 & Prospective design & $\begin{array}{l}\text { The similarity of psycho- } \\
\text { logical condition between } \\
\text { teacher and student and also } \\
\text { the involvement of motivation } \\
\text { from teacher indirectly affect } \\
\text { intrinsic motivation and their } \\
\text { persistency in sport through } \\
\text { their perception need regar- } \\
\text { ding the autonomy, compe- } \\
\text { tence, and relation. }\end{array}$ \\
\hline $\begin{array}{l}\text { Peer Motivational Cli- } \\
\text { mate in Youth Sport: } \\
\text { Measurement Develop- } \\
\text { ment and Validation }\end{array}$ & $\begin{array}{l}\text { Nikos Ntoumanis and } \\
\text { Spiridoula Vazou }\end{array}$ & 2005 & - & $\begin{array}{l}\text { The result shows that the use } \\
\text { of model with some consi- } \\
\text { derations which are approp- } \\
\text { riate and suitable with the } \\
\text { statement which states that } \\
\text { peer teacher is able to improve } \\
\text { students' motivation. }\end{array}$ \\
\hline $\begin{array}{l}\text { Peer-assisted learning in } \\
\text { school physical educa- } \\
\text { tion, sport and physical } \\
\text { activity programmes: a } \\
\text { systematic review }\end{array}$ & $\begin{array}{l}\text { Kate. A. Jenkinson, } \\
\text { Geraldine Naughton } \\
\text { and Amanda } \\
\text { C. Benson }\end{array}$ & 2014 & Systematic Review & $\begin{array}{l}\text { Peer teaching has been proved } \\
\text { as an effective learning stra- } \\
\text { tegy in improving the quality } \\
\text { of learning period, improving } \\
\text { physical activity, improving } \\
\text { moving skill, improving heal- } \\
\text { thy life behavior, developing } \\
\text { interaction and social skill. }\end{array}$ \\
\hline $\begin{array}{l}\text { A didactic analysis of } \\
\text { content development } \\
\text { during the peer teaching } \\
\text { tasks of a Sport Educa- } \\
\text { tion season }\end{array}$ & $\begin{array}{l}\text { Tristan Wallheada } \\
\text { and Mary O'Sullivanb }\end{array}$ & 2007 & Systematic Review & $\begin{array}{l}\text { The analysis of changing in } \\
\text { knowledge and performance } \\
\text { of students as the result of the } \\
\text { teaching partner indicates that } \\
\text { students understand and con- } \\
\text { sistently do many solutions for } \\
\text { the offensive rugby problem, } \\
\text { including to defend the belon- } \\
\text { ging and use the space. }\end{array}$ \\
\hline $\begin{array}{l}\text { The effects of peer } \\
\text { teaching on the univer- } \\
\text { sity students achieve- } \\
\text { ments in cognitive, } \\
\text { affective, psychomotor } \\
\text { domains and game per- } \\
\text { formances in volleyball } \\
\text { courses }\end{array}$ & $\begin{array}{ll}\text { Ayşe } & \text { Dilşad } \\
\text { Mirzeoğlu } & \end{array}$ & 2014 & experiment & $\begin{array}{l}\text { Peer teaching learning model } \\
\text { can more significantly in- } \\
\text { crease students' cognitive skill } \\
\text { than the conventional learning. } \\
\text { So do with the students' skill } \\
\text { in playing volleyball at the } \\
\text { experiment group which is } \\
\text { better than the control group. }\end{array}$ \\
\hline
\end{tabular}


End of the Table 1

\begin{tabular}{|c|c|c|c|c|}
\hline 1 & 2 & 3 & 4 & 5 \\
\hline $\begin{array}{l}\text { Peers as Teachers in } \\
\text { Physical Education Hip } \\
\text { Hop Classes in Finnish } \\
\text { High School } \\
\text { (Peer tutor as the tea- } \\
\text { cher in physical educa- } \\
\text { tion at every Hip Hop } \\
\text { class in Finland) }\end{array}$ & $\begin{array}{l}\text { Anna-Maria Nurmi \& } \\
\text { Marja }\end{array}$ & 2015 & Qualitative & $\begin{array}{l}\text { The peer teacher for dance } \\
\text { subject is considered as the } \\
\text { important subject in the } \\
\text { weekly curriculum. } \\
\text { In other sides, partner teachers } \\
\text { enjoy the freedom to make the } \\
\text { class as theirs. The learning } \\
\text { process becomes quicker and } \\
\text { students' self-confidence is } \\
\text { increased. } \\
\text { In other sides, many of them } \\
\text { are critical to themselves and } \\
\text { feeling ashamed when make } \\
\text { mistakes. They also feel un- } \\
\text { comfortable to teach the peer } \\
\text { tutor or the person who is } \\
\text { older than them, and surprise } \\
\text { to the unpredictable characte- } \\
\text { ristics such as arrogant chara- } \\
\text { cteristic. } \\
\text { This article illustrates that the } \\
\text { difficulties are not only found } \\
\text { by the experiment of partner- } \\
\text { teaching, but also the value of } \\
\text { peer teaching in offering the } \\
\text { positive experience and invol- } \\
\text { ving the students in physical } \\
\text { education class. }\end{array}$ \\
\hline $\begin{array}{l}\text { Mediating Peer Tea- } \\
\text { ching for Learning } \\
\text { Games: An Action Re- } \\
\text { search Intervention } \\
\text { Across Three Consecu- } \\
\text { tive Sport Education } \\
\text { Seasons }\end{array}$ & $\begin{array}{l}\text { Cláudio Farias, Isabel } \\
\text { Mesquita, Peter A. } \\
\text { Hastie, and Toni } \\
\text { O’Donovan }\end{array}$ & 2018 & Action research & $\begin{array}{l}\text { Through the implementation } \\
\text { of the systematical preparation } \\
\text { strategy, trainer-student can } \\
\text { successfully do the team } \\
\text { instruction which produces the } \\
\text { development of students' } \\
\text { tactic and the improvement of } \\
\text { work performances. } \\
\text { The aspects such as learning } \\
\text { dominant configuration of } \\
\text { players' gym and the tactical } \\
\text { principles which are similar in } \\
\text { all gyms especially in the } \\
\text { same category to prevent the } \\
\text { setback in learning content } \\
\text { complexity which is addressed } \\
\text { in the beginning if the season. } \\
\text { Players also show the impro- } \\
\text { vement of skill to adjust the } \\
\text { gameplay with the condition } \\
\text { of the game. } \\
\text { Conclusion: Although the } \\
\text { physical education has capa- } \\
\text { city to develop competent } \\
\text { players, every level of tea- } \\
\text { chers' guidance and instructi- } \\
\text { onal responsibility of students } \\
\text { is urgently needed when } \\
\text { teaching the tactics. }\end{array}$ \\
\hline
\end{tabular}


End of the Table 1

\begin{tabular}{|c|c|c|c|c|}
\hline 1 & 2 & 3 & 4 & 5 \\
\hline $\begin{array}{l}\text { Improving Academic } \\
\text { Performance of Sport } \\
\text { and Exercise Science } \\
\text { Undergraduate Students } \\
\text { in Gross Anatomy } \\
\text { Using a Near-Peer Tea- } \\
\text { ching Program }\end{array}$ & $\begin{array}{l}\text { Ricardo Borges Viana, } \\
\text { Mario Hebling Cam- } \\
\text { pos, Douglas de Assis } \\
\text { Teles Santos, Isabela } \\
\text { Cristina Maioni Xa- } \\
\text { vier, Rodrigo Luiz } \\
\text { Vancini, Marı'lia San- } \\
\text { tos Andrade \& Claudio } \\
\text { Andre Barbosa de Lira }\end{array}$ & 2018 & $\begin{array}{l}\text { Retrospective cross- } \\
\text { sectional research }\end{array}$ & $\begin{array}{l}\text { The final academic score of } \\
\text { students which follows the } \\
\text { peer teaching learning pro- } \\
\text { gram is higher which is signi- } \\
\text { ficantly seen rather than does } \\
\text { not follow the program. }\end{array}$ \\
\hline $\begin{array}{l}\text { The effects of forma- } \\
\text { lized and trained non- } \\
\text { reciprocal peer teaching } \\
\text { on psychosocial, beha- } \\
\text { vioral, pedagogical, and } \\
\text { motor learning outco- } \\
\text { mes in physical educa- } \\
\text { tion }\end{array}$ & $\begin{array}{l}\text { Peter R. Whipp, Ben } \\
\text { Jackson, James A. } \\
\text { Dimmock \& Jenny } \\
\text { Soh }\end{array}$ & 2015 & Experiment & $\begin{array}{l}\text { The data collect more than } \\
10 \text { lessons in football unit for } \\
\text { five weeks. It is significantly } \\
\text { improved in the game work } \\
\text { action among students who } \\
\text { join the program. } \\
\text { The students who are included } \\
\text { to T-PT also provide the } \\
\text { feedback level and the more } \\
\text { structured learning period to } \\
\text { report more positive feelings } \\
\text { about the peer teaching and } \\
\text { less obstacles faced in asses- } \\
\text { sing the learning output. } \\
\text { The finding shows that the } \\
\text { reciprocal partner-teacher } \\
\text { which accepts the supports } \\
\text { through the training and the } \\
\text { resource tactical approach } \\
\text { based learning which can } \\
\text { improve the performance of } \\
\text { behavior, pedagogy, and } \\
\text { motoric in physical education. }\end{array}$ \\
\hline $\begin{array}{l}\text { Reciprocal peer tutoring } \\
\text { in a physical education } \\
\text { setting: } \\
\text { influence of peer tutor } \\
\text { training and gender on } \\
\text { motor performance and } \\
\text { self-efficacy outcomes. }\end{array}$ & $\begin{array}{l}\text { Pierre Jean Enser- } \\
\text { gueix \& Lucile Lafont }\end{array}$ & 2010 & Experiment & $\begin{array}{l}\text { In this research, the partici- } \\
\text { pants obtain better motoric } \\
\text { development and manifest the } \\
\text { belief of self-efficacy which is } \\
\text { more accurate from their } \\
\text { partners from only physical } \\
\text { training and spontaneity. } \\
\text { That all beginner students } \\
\text { obtain benefits from the } \\
\text { symmetrical pair training and } \\
\text { the role of teachers in mana- } \\
\text { ging table tennis only if they } \\
\text { have been prepared before. }\end{array}$ \\
\hline $\begin{array}{l}\text { Effects of Peer Medi- } \\
\text { ated Instruction with } \\
\text { Task Cards on Motor } \\
\text { Skill Acquisition in } \\
\text { Tennis }\end{array}$ & $\begin{array}{l}\text { Peter Iserbyt, } \text { Bob } \\
\text { Madou, Lieven Ver- } \\
\text { gauwen, Daniel Be- } \\
\text { hets }\end{array}$ & 2016 & Experiment & $\begin{array}{l}\text { The finding shows that peer } \\
\text { mediated learning by using } \\
\text { assignment card which is } \\
\text { almost same with the format } \\
\text { centered on teachers in tech- } \\
\text { nical sport such as tennis. Be- } \\
\text { sides that, it is also discussed } \\
\text { that the managing of peer } \\
\text { mediated learning can offer } \\
\text { strong learning environment, } \\
\text { emphasizing the social purpo- } \\
\text { se and also the motor in phy- } \\
\text { sical education. }\end{array}$ \\
\hline
\end{tabular}


End of the table 1

\begin{tabular}{|c|c|c|c|c|}
\hline 1 & 2 & 3 & 4 & 5 \\
\hline $\begin{array}{l}\text { Improving Academic } \\
\text { Performance of Sport } \\
\text { and Exercise Science } \\
\text { Undergraduate Students } \\
\text { in Gross Anatomy } \\
\text { Using a Near-Peer Tea- } \\
\text { ching Program }\end{array}$ & $\begin{array}{l}\text { Ricardo Borges Viana, } \\
\text { Mario Hebling Cam- } \\
\text { pos, Douglas de Assis } \\
\text { Teles Santos, Isabela } \\
\text { Cristina Maioni Xa- } \\
\text { vier, Rodrigo Luiz } \\
\text { Vancini, Marı'lia San- } \\
\text { tos Andrade, Claudio } \\
\text { Andre Barbosa de } \\
\text { Lira }\end{array}$ & 2016 & Action research & $\begin{array}{l}\text { This study shows that the } \\
\text { learning program of close } \\
\text { partner which is implemented } \\
\text { in a university about functi- } \\
\text { onal anatomy from locomotors } \\
\text { tool is an effective, decent, } \\
\text { and reachable strategy to } \\
\text { improve the academic perfor- } \\
\text { mance of students in sport } \\
\text { bachelor degree program and } \\
\text { the exercise of sciences. } \\
\text { Besides that, the findings also } \\
\text { contribute to the understand- } \\
\text { ding of the values from some } \\
\text { programs and potential effects } \\
\text { to the students' academic per- } \\
\text { formance. } \\
\text { For the institution which has } \\
\text { similar program, the policy of } \\
\text { the institution should stimulate } \\
\text { students' participation, especi- } \\
\text { ally for them who have dif- } \\
\text { ficulties in learning and / or } \\
\text { low academic achievement. } \\
\text { Finally, the teaching program } \\
\text { of the close partner which is } \\
\text { reported and have functions as } \\
\text { the model for other institu- } \\
\text { tions. }\end{array}$ \\
\hline $\begin{array}{l}\text { Peer-to-peer Teaching } \\
\text { in Higher Education: } \\
\text { A Critical Literature } \\
\text { Review }\end{array}$ & Martin Stigmar & 2003 & Literature Review & $\begin{array}{l}\text { The peer teaching learning } \\
\text { model produces the benefits of } \\
\text { academic achievement and } \\
\text { other pedagogical advantages } \\
\text { such as increasing students } \\
\text { critical thinking, motivation, } \\
\text { collaboration, and communi- } \\
\text { cative skill. }\end{array}$ \\
\hline $\begin{array}{l}\text { Peer-Assisted Learning } \\
\text { in Physical Education: } \\
\text { A Review of Theory } \\
\text { and Research }\end{array}$ & $\begin{array}{l}\text { Phillip Ward and } \\
\text { Myung-Ah Lee }\end{array}$ & 2005 & Literature Review & $\begin{array}{l}\text { Although one of the studies } \\
\text { does not show significant dif- } \\
\text { ference, but in } 14 \text { other studies } \\
\text { with special intervention show } \\
\text { the improvement of academic } \\
\text { learning period, improving } \\
\text { physical activity from medium } \\
\text { to strong, improving the right } \\
\text { work percentage of motoric } \\
\text { skill, and improve the scores } \\
\text { in motoric skill test. }\end{array}$ \\
\hline
\end{tabular}

Furthermore, peer teaching is proven as an effective teaching model [21], in improving the quality and improvement in the academic learning and also can improve the involvement of physical activity $[21 ; 27 ; 28]$, improve the moving skill $[21 ; 26 ; 27 ; 28 ; 29 ; 30 ; 22 ; 31 ; 32 ; 33 ; 34]$, improve healthy life behavior [21], develop the interaction and social skill [21;33]. The improvement of moving skill produced by peer teaching model is very various, not only in one kind of sport but also in other kinds of sport.

Besides the improvement of motoric aspect, peer teaching also gives the improvement on students' cognitive aspect [30;35] and it seems easier to find solution from the problem in a learning process [29], the 
improvement of students' critical thinking skill [18], it is obviously shown by the improvement of students' final score $[18 ; 31]$. The other academic benefits obtained by the using of peer teaching learning model such as to improve students' confidence [32;34;35], and to improve students' communication skill [18]. To monitor the improvement process of motivation and learning result through peer teaching model, as presented in diagram. 1 below:

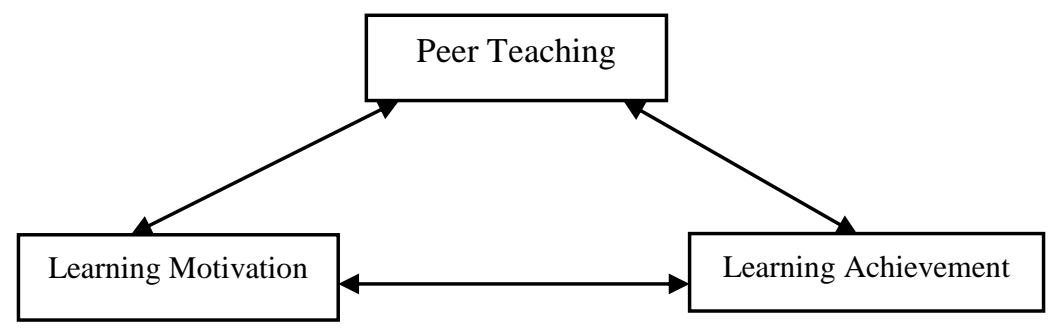

Diagram. 1. The Use of Peer Teaching Learning Model and the Improvement of Motivation and Students' Learning Achievement

Discussion. The good learning should be enjoyable for students [5;6], and it can improve students' learning motivation. If the motivation of students in attending the learning process in class is good, it will affect the improvement of students' learning achievement [25; 26]. Teacher should be careful in using learning method which can support all aspects which are involved. One of them is by conducting peer teaching learning model.

a) How Peer Teaching Can Give Motivation and Improve Students' Learning Achievements.

Peer teaching is one of compensational learning models. This method is enjoyable not only for students but also for teachers [5;6]. For students, the age distance and the same status with tutor make them comfort and more active in interacting [25]. Whereas, for teachers, it will decrease the teaching duty and will more focus to the supervision of the learning as appropriate with the learning objectives. There are some reasons why the peer teaching learning model can improve students' motivation and learning achievement:

1) The close psychological distance between tutor and tutee makes them becoming more intensive in communication [25].

2) The good tutor will give more motivations for students [25].

3) For tutor, belief and motivation are improved becoming the belief from teachers to them in giving the lesson material. For tutee, the motivation is increasing because there is no clumsiness in interacting either in asking or responding.

4) For tutor, by the obligation of mastering the materials before the class, makes the learning achievements becoming better. And for tutee by the increasing of motivation, there is intensive interaction in learning that makes the learning achievement becoming better [25; 26].

b) The Things to be Noticed in Implementing the Peer Teaching Learning Method.

The peer teaching learning model has many benefits, but every learning model should have the strengths and weaknesses.

1) It is difficult to find student who is convenient to be made as tutor, because the quality of tutor also affects the learning [26] should be responded with earlier preparation.

2) Doing some detail monitoring to anticipate the students who have less participation in learning.

c) Recommendation.

From the analysis of all collected data, there are some recommendations that the writer wants to deliver.

1) The peer teaching learning model can be used in every level of education.

2) Peer teaching learning model will be more effective if accompanied by additional teaching media such as task card [33] and other kinds of media.

3) In many writings, the peer teaching learning method is often used in field practice learning which trains the psychomotor skill, but still can improve other domains such as cognitive and affective.

\section{References}

1. Febianti, Y. N. (2014). Peer Teaching (Tutor Sebaya) Sebagai Metode Pembelajaran Untuk Melatih Siswa Mengajar. Edunomic Jurnal Pendidikan Ekonomi, 2(2).

2. Dörnyei, Z., \& Csizér, K. (1998). Ten commandments for motivating language learners: Results of an empirical study. Language teaching research, 2(3), 203-229. 
3. Kusumah, M. I., Sutisna, S., \& Septian, D. (2018). Pengaruh Metode Pembelajaran Tutor Sebaya (Peer Teaching) Terhadap Hasil Belajar Siswa Pada Mata Pelajaran Fisika Pokok Bahasan Vektor Kelas X MIPA MAN 1 Cirebon. Jurnal Pendidikan Fisika dan Sains (JPFS), 1(1), 33-39.

4. Sagala, S. (2010). Konsep dan Makna Pembelajaran. Bandung: Alfabeta.

5. Alwi, M. (2009). Pengaruh metode tutor sebaya terhadap motivasi dan prestasi belajar matematika siswa SMA. TesisFakultas Psikologi UGM, Yogyakarta.

6. Lim, L. L. (2014). A Case Study on Peer Teaching. Open Journal of Social Sciences, 2(8), 35-40.

7. Bradford-Watts, K. (2011). Students teaching students? Peer teaching in the EFL classroom in Japan. The Language Teacher, 35(5), 32-35.

8. Ntoumanis N and Standage M (2009) Motivation in physical education classes: A self-determination theory perspective. Theory and Research in Education, 7(2), 194-202.

9. Van den Berghe L, Vansteenkiste M, Cardon G, et al. (2014) Research on self-determination in physical education: Key findings and proposals for future research. Physical Education \& Sport Pedagogy, 19(1), 97-121.

10. Ntoumanis, N. (2005). 'A prospective study of participation in optional school physical education based on self-determination theory', Journal of Educational Psychology, 97, 444-53.

11. Vansteenkiste, M., Simons, J., Lens, W., Sheldon, K. M., Deci, E. L. (2004). Motivating learning, performance, and persistence: The synergistic effects of intrinsic goal contents and autonomy-supportive contexts. J Pers Soc Psychol, 87(2), 246-260.

12. Vansteenkiste, M., Simons, J., Lens, W., Soenens, B., Matos, L. (2005). Examining the motivational impact of intrinsic versus extrinsic goal framing and autonomy-supportive versus internally controlling communication style on early adolescents' academic achievement. Child Dev, 76(2), 483-501.

13. Hustinx, P. W. J., Kuyper, H., van der Werf, M. P. C., Dijkstra, P. (2009). Achievement motivation revisited: New longitudinal data to demonstrate its predictive power. Educ Psychol,29(5), 561-582.

14. Mouratidis, M., Vansteenkiste, M., Lens, W. and Sideridis, G. (2008) 'The motivating role of positive feedback in sport and physical education: Evidence for a motivational model', Journal of Sport and Exercise Psychology, 30, 240-68.

15. Ntoumanis, N. (2001) 'A self-determination approach to the understanding of motivation in physical education', British Journal of Educational Psychology, 71, 225-42.

16. Standage, M., Duda, J. L. and Ntoumanis, N. (2005) 'A test of self-determination theory in school physical education', British Journal of Educational Psychology, 75, 411-33.

17. Kusurkar, R. A., Ten Cate, T. J., Van Asperen, M., \& Croiset, G. (2011). Motivation as an independent and a dependent variable in medical education: a review of the literature. Medical teacher, 33(5), e242-e262.

18. Stigmar, M. (2016). Peer-to-peer teaching in higher education: A critical literature review. Mentoring \& Tutoring: Partnership in Learning, 24(2), 124-136.

19. Dikmen, Y., Ak, B., Yildirim Usta, Y., Ünver, V., Akin Korhan, E., Cerit, B., \& Yönder Ertem, M. (2017). Effect of peer teaching used in nursing education on the performance and competence of students in practical skills training. International Journal of Educational Sciences, 16(1-3), 14-20.

20. Marc Campolo, P. T., Maritz, C. A., Gregory Thielman, P. T., \& Lora Packel, M. S. (2013). An evaluation of peer teaching across the curriculum: student perspectives. International Journal of Therapies and Rehabilitation Research, 2(1), 1.

21. Jenkinson, K. A., Naughton, G., \& Benson, A. C. (2014). Peer-assisted learning in school physical education, sport and physical activity programmes: a systematic review. Physical Education and Sport Pedagogy, 19(3), 253-277.

22. Farias, C., Mesquita, I., Hastie, P. A., \& O’Donovan, T. (2018). Mediating peer teaching for learning games: An action research intervention across three consecutive Sport Education seasons. Research quarterly for exercise and sport, 89(1), 91-102.

23. Wolfswinkel, Joost F, Elfi Furtmueller and Celeste P M Wilderom. (2013). Using grounded theory as a method for rigorously reviewing literature. European Journal of Information Systems, 22, 45-55.

24. Ntoumanis, N., \& Vazou, S. (2005). Peer motivational climate in youth sport: Measurement development and validation. Journal of Sport and Exercise Psychology, 27(4), 432-455.

25. Jõesaar, H., Hein, V., \& Hagger, M. S. (2011). Peer influence on young athletes' need satisfaction, intrinsic motivation and persistence in sport: A 12-month prospective study. Psychology of Sport and Exercise, 12(5), 500-508.

26. d'Arripe-Longueville, F., Gernigon, C., Huet, M. L., Cadopi, M., \& Winnykamen, F. (2002). Peer tutoring in a physical education setting: Influence of tutor skill level on novice learners' motivation and performance. Journal of Teaching in Physical Education, 22(1), 105-123.

27. Ward, P., Lee, M. A., \& Lee, M. A. (2005). Peer-assisted learning in physical education: A review of theory and research. Journal of teaching in physical education, 24(3), 205-225. 
28. Whipp, P. R., Jackson, B., Dimmock, J. A., \& Soh, J. (2015). The effects of formalized and trained nonreciprocal peer teaching on psychosocial, behavioral, pedagogical, and motor learning outcomes in physical education. Frontiers in psychology, 6, 149.

29. Wallhead, T., \& O'sullivan, M. (2007). A didactic analysis of content development during the peer teaching tasks of a sport education season. Physical Education and Sport Pedagogy, 12(3), 225-243.

30. Mirzeoğlu, A. D. (2014). The effects of peer teaching on the university students achievements in cognitive, affective, psychomotor domains and game performances in volleyball courses. Educational Research and Reviews, 9(9), 262-271.

31. Viana, R. B., Campos, M. H., Santos, D. D. A. T., Xavier, I. C. M., Vancini, R. L., Andrade, M. S., \& de Lira, C. A. B. (2018). Improving academic performance of sport and exercise science undergraduate students in gross anatomy using a near-peer teaching program. Anatomical sciences education, 12(1), 74-81.

32. Ensergueix, P. J., \& Lafont, L. (2010). Reciprocal peer tutoring in a physical education setting: influence of peer tutor training and gender on motor performance and self-efficacy outcomes. European Journal of Psychology of Education, 25(2), 222-242.

33. Iserbyt, P., Madou, B., Vergauwen, L., \& Behets, D. (2011). Effects of peer mediated instruction with task cards on motor skill acquisition in tennis. Journal of Teaching in Physical Education, 30(1), 31-50.

34. Legrain, P., d'Arripe-Longueville, F., \& Gernigon, C. (2003). Peer tutoring in a sport setting: Are there any benefits for tutors? The Sport Psychologist, 17(1), 77-94.

35. Nurmi, A. M., \& Kokkonen, M. (2015). Peers as teachers in physical education hip hop classes in Finnish high school. Journal of Education and Training Studies, 3(3), 23-32.

36. Vansteenkiste M, Simons J, Lens W, Sheldon KM, Deci EL. 2004. Motivating learning, performance, and persistence: The synergistic effects of intrinsic goal contents and autonomy-supportive contexts. J Pers Soc Psychol, 87(2), 246-260.

37. Vansteenkiste M, Simons J, Lens W, Soenens B, Matos L. 2005a. Examining the motivational impact of intrinsic versus extrinsic goal framing and autonomy-supportive versus internally controlling communication style on early adolescents' academic achievement. Child Dev, 76(2), 483-501.

38. Hustinx PWJ, Kuyper H, van der Werf MPC, Dijkstra P. 2009. Achievement motivation revisited: New longitudinal data to demonstrate its predictive power. Educ Psychol, 29(5), 561-582.

39. Mouratidis, M., Vansteenkiste, M., Lens, W. and Sideridis, G. (2008) 'The motivating role of positive feedback in sport and physical education: Evidence for a motivational model', Journal of Sport and Exercise Psychology, 30, 240-68.

40. Ntoumanis, N. (2001) 'A self-determination approach to the understanding of motivation in physical education', British Journal of Educational Psychology, 71, 225-42.

41. Standage, M., Duda, J.L. and Ntoumanis, N. (2005) 'A test of self-determination theory in school physical education', British Journal of Educational Psychology, 75, 411-33.

42. Kusurkar, R. A., Ten Cate, T. J., Van Asperen, M., \& Croiset, G. (2011). Motivation as an independent and a dependent variable in medical education: a review of the literature. Medical teacher, 33(5), e242-e262.

43. Stigmar, M. (2016). Peer-to-peer teaching in higher education: A critical literature review. Mentoring \& Tutoring: Partnership in Learning, 24(2), 124-136.

44. Dikmen, Y., Ak, B., Yildirim Usta, Y., Ünver, V., Akin Korhan, E., Cerit, B., \& Yönder Ertem, M. (2017). Effect of peer teaching used in nursing education on the performance and competence of students in practical skills training. International Journal of Educational Sciences, 16(1-3), 14-20.

45. Marc Campolo, P. T., Maritz, C. A., Gregory Thielman, P. T., \& Lora Packel, M. S. (2013). An evaluation of peer teaching across the curriculum: student perspectives. International Journal of Therapies and Rehabilitation Research, 2(1), 1.

46. Jenkinson, K. A., Naughton, G., \& Benson, A. C. (2014). Peer-assisted learning in school physical education, sport and physical activity programmes: a systematic review. Physical Education and Sport Pedagogy, 19(3), 253-277.

47. Farias, C., Mesquita, I., Hastie, P. A., \& O’Donovan, T. (2018). Mediating peer teaching for learning games: An action research intervention across three consecutive Sport Education seasons. Research quarterly for exercise and sport, 89(1), 91-102.

48. Iserbyt, P., Madou, B., Vergauwen, L., \& Behets, D. (2011). Effects of peer mediated instruction with task cards on motor skill acquisition in tennis. Journal of Teaching in Physical Education, 30(1), 31-50.

49. Nurmi, A. M., \& Kokkonen, M. (2015). Peers as teachers in physical education hip hop classes in Finnish high school. Journal of Education and Training Studies, 3(3), 23-32.

50. Viana, R. B., Campos, M. H., Santos, D. D. A. T., Xavier, I. C. M., Vancini, R. L., Andrade, M. S., \& de Lira, C. A. B. (2018). Improving academic performance of sport and exercise science undergraduate students in gross anatomy using a near-peer teaching program. Anatomical sciences education. 
51. Wallhead, T., \& O'sullivan, M. (2007). A didactic analysis of content development during the peer teaching tasks of a sport education season. Physical Education and Sport Pedagogy, 12(3), 225-243.

52. Ward, P., Lee, M. A., \& Lee, M. A. (2005). Peer-assisted learning in physical education: A review of theory and research. Journal of teaching in physical education, 24(3), 205-225.

53. Whipp, P. R., Jackson, B., Dimmock, J. A., \& Soh, J. (2015). The effects of formalized and trained nonreciprocal peer teaching on psychosocial, behavioral, pedagogical, and motor learning outcomes in physical education. Frontiers in psychology, 6, 149.

Стаття надійшла до редакції 02.01.2020 p. 